\section{Last interglacial in Devils Hole}

SIR - Broecker in News and Views ${ }^{1}$ confessed himself confused by the apparent contradiction between the chronologies for the last interglacial presented by the Devils Hole (Nevada) calcite vein $^{2}$ and that generally accepted by adherents to the Milankovitch theory ${ }^{3}$. I suggest that the discrepancy arises from an unforeseen consequence of dating this unusual deposit by measuring the growth of ${ }^{230} \mathrm{Th}$ from its parent ${ }^{234} \mathrm{U}$.

The oxygen-isotope record from core DH11 (ref. 4), obtained from a calcite crust in the Devils Hole, provides an apparently amazing confirmation of the global validity of the continuous marine $\delta^{18} \mathrm{O}$ records as a description of the first order pattern of the ice ages. Almost every detail in the SPECMAP stacked $\delta^{18} \mathrm{O}$ record $^{3}$ can be recognized in this precisely dated core which is only $36 \mathrm{~cm}$ long (Fig. 3 of ref. 4). The one apparent discrepancy that leads these authors ${ }^{2}$ eloquently to disagree with the authors of the SPECMAP paper ${ }^{3}$ is a seemingly crucial disagreement in the timing of the onset of the last interglacial.

The Devils Hole is a water-filled fault fissure about $1.2 \mathrm{~m}$ wide lined with a thick layer of calcite; it is this layer of calcite that was sampled. The calcite and associated uranium has been deposited from the water. Ages are estimated from the ingrowth of ${ }^{230} \mathrm{Th}$ in apparently technically ideal conditions ${ }^{2}$. The average accumulation rate is about $0.6 \mathrm{~mm}$ per $\mathrm{kyr}$, although over the critical interval of interest $5.5 \mathrm{~mm}$ accumulated between 149.8 and $131.9 \mathrm{kyr}$, a rate of about 0.3 $\mathrm{mm}$ per kyr. If we envisage the water from half the width of the fissure contributing to the calcite on each side, then out of the $0.6 \mathrm{~m}$ thick layer of water, calcite was deposited at a rate of $0.8 \times$ $10^{-4} \mathrm{~g} \mathrm{~cm}^{-2}$ of surface per year. The calcite contains about 0.5 p.p.m. uranium (Table 1 of ref. 5) so that uranium is deposited at a mean rate of $0.4 \times$ $10^{-10} \mathrm{~g} \mathrm{~cm}^{-2}$ of surface per year.

An important difference between the Devils Hole situation and the cave spelaeothems that have usually been dated by this method (reviewed in ref. 6) is that the vein is continuously in water. This difference is important because one must consider the fate of the ${ }^{230} \mathrm{Th}$ that

\section{Scientific Correspondence}

Scientific Correspondence is intended to provide a forum in which readers may raise points of a scientific character. They need not arise out of anything published in Nature. In any case, priority will be given to letters of fewer than 500 words and five references. is produced by decay of dissolved ${ }^{234} \mathrm{U}$ in the water. A layer of water $0.6 \mathrm{~m}$ thick and containing 3 p.p.b. uranium (ref. 7 and I. J. Winograd, personal communication) represents $0.18 \times 10^{-6} \mathrm{~g}$ of uranium per $\mathrm{cm}^{2}$ of the fissure face, and thus will generate in one year a quantity of ${ }^{230} \mathrm{Th}$ about $4.5 \times 10^{5}$ times the amount generated by the decay of the uranium in one year's accumulation on the vein. Because thorium is very insoluble, this ${ }^{230} \mathrm{Th}$ will immediately attach to the surfaces of the cavern, so that even though the ${ }^{232} \mathrm{Th}$ concentration of the calcite is negligible, zero-age calcite could have an apparent age of the order of $5 \times 10^{3} \mathrm{yr}$ if age is estimated on the assumption that freshly deposited calcite contains no ${ }^{230} \mathrm{Th}$. Although this ${ }^{230} \mathrm{Th}$ excess will decay with time, its contribution to the apparent age remains a constant number of years. Moreover, the initial age error would vary inversely with the growth rate; it would be difficult to interpret the apparent $60 \mathrm{kyr}$ age obtained for the outer part of the calcite where calcite accumulation must have slowed towards zero with an ever increasing "initial age", although the excellent ${ }^{234} \mathrm{U}^{238} \mathrm{U}$ data provide a valuable constraint.

I conclude that rather than being a thorn in our flesh, the record generated by Winograd and colleagues ${ }^{4}$ is both the most impressive record of the ice ages from the American continent, and a remarkable demonstration of the ubiquity of the characteristic record that has been so widely documented in the sediments of the deep ocean. The general validity of the timescale currently in use is strongly supported by the impressive ${ }^{234} \mathrm{U}$ chronology ${ }^{2}$, but despite the technical excellence of the ${ }^{230} \mathrm{Th}$ measurements, I suggest that the potentially large contribution from unsupported ${ }^{230} \mathrm{Th}$ precludes their use to refine our best estimate for the age of the last interglacial.

\section{N. J. Shackleton}

Godwin Laboratory for Quaternary Research,

University of Cambridge,

Cambridge CB2 3RS, UK

LUDWIG ET AL. REPLY - Our disagreement with SPECMAP and with the Milankovitch hypothesis stems not only from the "timing of the onset of the last interglacial", as claimed by Shackleton, but also from the following features of the Devils Hole record: the 20 -kyr duration of the interglacial climates; an increasing duration of the quasi-100-kyr cycle as we come forward in time; and the occurrence of a well-developed glacial cycle at 350-450 kyr when the insolation theory indicates none should occur $^{4}$

With regard to the ${ }^{230} \mathrm{Th}$ excess issue, properly raised by Shackleton, we note that: (1) groundwater flow in Devils Hole is laminar, whereas turbulent flow would be required to efficiently transfer water-generated ${ }^{230} \mathrm{Th}$ to the cavern walls; (2) particulate scavenging of ${ }^{230} \mathrm{Th}$, followed by gravitational settling, is strongly suggested by the contrast between the textures of footwall vein calcite compared to hanging wall vein calcite. (Footwall calcite in Devils Hole is coloured and finely banded, whereas hanging wall calcite - such as samples DH-11 and DH-2 - is white-toyellowish white and rarely banded.); (3) the necessity of allowing for groundwater travel time means that the age of the onset of the last interglacial recorded in DH-11 (140 $\pm 3 \mathrm{kyr})$ must itself be too young by several thousand years; and (4) most conclusively, since receipt of an earlier draft of Shackleton's correspondence, we have measured the ${ }^{230} \mathrm{Th}-{ }^{234} \mathrm{U}-$ ${ }^{238} \mathrm{U}$ of the outermost surface (to a depth of $40-50 \mu \mathrm{m}$ ) of vein samples $\mathrm{DH}-2$ and $\mathrm{DH}-11$ and found only a negligible fraction $(<1 \%)$ of the excess ${ }^{230} \mathrm{Th}$ predicted by Shackleton. These analyses $^{8}$ show that the effect of watergenerated excess ${ }^{230} \mathrm{Th}$, accumulated on the surface of these veins during the past $60 \mathrm{kyr}$, corresponds to an age-bias of less than 20 years over the entire history of vein calcite accumulation for DH-11 and DH-2.

Shackleton reasonably asks whether ${ }^{230} \mathrm{Th}$ in the Devils Hole water column could have significantly affected the accuracy of the ages we reported ${ }^{2,4}$. However, neither the character of the aqueous environment, the petrology of the calcite, nor direct measurements of excess ${ }^{230} \mathrm{Th}$ on the surface of the veins supports the 5 kyr age-bias suggested by Shackleton.

The Devils Hole dates ${ }^{2,4}$ therefore remain a challenge to the Milankovitch hypothesis.

K. R. Ludwig

K. R. Simmons

I. J. Winograd

B. J. Szabo

J. M. Landwehr

A. C. Riggs

US Geological Survey,

Denver Federal Center,

Lakewood,

Colorado 80225, USA

1. Broecker, W. S. Nature 359, 779-780 (1992).

2. Ludwig, K. R. et al. Science 258, 284-287 (1992)

3. Imbrie, J. et al. in Milankovitch and Climate (eds Berger, A. et al.) part 1, 269-305 (Reidel, Dordrecht, 1984)

4. Winograd, I. J. et al. Science 258, 255-260 (1992).

5. Winograd, I. J. et al. Science 242, 1275-1280 (1988).

6. Gascoyne, M. \& Schwarcz, H. P. in Uranium Series Disequilibrium: Applications to Environmental Problems (eds Ivanovich, M. \& Harmon. R. S.) 268-300 (Clarendon, Oxford, 1982)

7. Osmond, J. K. \& Cowart, J. B. in Uranium Series Disequilibrium: Applications to Environmental Problems (eds Ivanovich, M. \& Harmon, R. S.) 202 (Clarendon. Oxford, 1982),

8. Ludwig, K. R. et al. Science 259, 1626 (1993). 